\title{
Oxidation of glycerol, lactate, and propionate by Propionibacterium freudenreichii in a poised-potential amperometric culture system
}

\author{
Rainer Emde and Bernhard Schink \\ Lehrstuhl M1krobılogie 1 der Eberhard-Karls-Universität. Auf der Morgenstelle 28, D-7400 Tübingen, Federal Republic of Germany
}

Received October 17, 1989/Accepted January 2, 1990

\begin{abstract}
Growth of Propionibacterium freudenreichii was studied with glycerol, lactate, and propionate as energy sources and a three-electrode poised-potential amperometric electrode system with hexacyanoferrate (III) as mediator. In bateh culture cxperiments with glycerol and lactate as substrates, hexacyanoferrate (III) was completcly reduced. Growth yields increased and the fermentation patterns were shifted towards higher acetate formation with increasing hexacyanoferrate (III) concentrations $(0.25-8.0 \mathrm{mM})$. In experiments with regulated clectrodes, glycerol, lactate, and propionate were oxidized to acetate and $\mathrm{CO}_{2}$, and the electrons were quantitatively transferred to the working electrode. Growth yields of $29.0,13.4$ and $14.2 \mathrm{~g}$ cell material per mol wore calculated, respectively. The high cell yield obtained during propionate oxidation cannot be explained solcly by substrate level phosphorylation indicating that additional energy was conserved via electron transport phosphorylation. Furthermore, this result indicated complete reversibility of the methyl-malonyl-CoA pathway in propionic acid bacteria.
\end{abstract}

Key words: Propionic acid bacteria - Propionibacterium sp. - Methyl-malonyl-CoA pathway - Electron transport phosphorylation - Hexacyanoferrate (III) Poised-polential amperometric system

Bacteria of the genus Propionibacterium are regarded as anaerobic bacteria which ferment lactate or glucose to propionate, acelate, and $\mathrm{CO}_{2}$ in a ratio of $2: 1: 1$, as proposed for the first time by Fitz (1878). During this fermentation, electrons released in acetate formation are consumed for propionate production via malate dehydrogenase and fumarate reductase reaction (Schink 1988).

Reduction of external electron acceptors is possible as well. In cultures of Propionibacterium freudenreichii,

Offprint requests to: R. Emde growth rate and growth yield increased in the presence of oxygen at low concentrations (De Vries et al. 1972; Van Gent-Ruyters et al. 1976). Presence of cytochrome b, cytochrome $a_{1}$, cytochrome $d$, and a CO-binding pigment (cytochrome o) was reported (Chaix and Fromageot 1942; Sone 1972; De Vries et al. 1972; Schwartz and Sporkenbach 1975), and it was concluded that they function in electron transport to oxygen and fumarate (De Vries et al. 1973; Sone 1974). Also nitrate can be used as clcction acceptor by some propionibacteria, as demonstrated for Propionibacteritum pentosaceum (Van GentRuyters et al. 1975; Kaneko and Ishimoto 1978). Thus, propionic acid bacteria appear to possess a respiratory chain which is to some extent comparable to that of a number of aerobic and facultatively aerobic bacteria.

In a study on anaerobic degradation of glycerol by Escherichia coli, we found recently that hexacyanoferrate (III) could act as an artificial electron acceptor which replaced fumarate or nitrate during anaerobic growth (Emde et al. 1989). In the present study, the influence of continuously reoxidized hexacyanoferrate (III) on the fermentation melabolism of P.freudenreichii is described.

\section{Materials and methods}

\section{Bacteria and media}

Propionibacterim freudenrechil (DSM 20271) was obtained from the Deutsche Sammlung von Mikroorganismen GmbH, Braunschweig, FRG.

For all growth experiments, carbonate-buffered mineral medium with $0.2 \mathrm{~g} \mathrm{KH}_{2} \mathrm{PO}_{4}, 0.25 \mathrm{~g} \mathrm{NH} \mathrm{NH}_{4} \mathrm{Cl}, 3.0 \mathrm{~g} \mathrm{NaCl}, 0.4 \mathrm{~g}$ $\mathrm{MgCl}_{2} \times 6 \mathrm{H}_{2} \mathrm{O}, 0.5 \mathrm{~g} \mathrm{KCl}$ and $0.15 \mathrm{~g} \mathrm{CaCl}_{2} \times 2 \mathrm{H}_{2} \mathrm{O}$ per liter was prepared (Widdel and Pfennig 1981). The basal medium was autoclaved and the following components were added per liter medium under a $\mathrm{N}_{2} / \mathrm{CO}_{2}(90 \% / 10 \%)$ atmosphere: $30 \mathrm{ml}$ I $\mathrm{M} \mathrm{NaHCO}_{3}$ solution: $20 \mathrm{ml}$ yeast extract solution $(5 \% \mathrm{w} / \mathrm{v}) ; 1 \mathrm{ml}$ trace element solution SL 10 (W/ddel ot al. 1983); 1 ml selenite-tungstate solution (Tschech and Pfennig 1984);0.5 ml tenfold concentrated 7-vitamin. solution (Piennig 1978). The $\mathrm{pH}$ was adjusted to 7.2-7.4, and the complete medium was filled into sterle screw-cap bottles. 


\section{Culture conditions}

Expcriments in the presence of regulated electrodes were performed In an anoxic three-clectrode poised-potential amperometric system described earlier (Emde et al. 1989). Berore use, the culture vessel, the counter electrode (a platinum wire with a surface of about $1.5 \mathrm{~cm}^{2}$ ), the working electrode (a platmum net with an overall surface of about $40 \mathrm{~cm}^{2}$ ), and the reference electrode wire (a silverchloride coated silver wire) were autoclaved. The electrodes were connected to a Laboratory potentiostat (Type LB $81 \mathrm{M}$, Bank Flek tronik, Gotlingen, FR G), and the working electrode was poised at a prescl potential against the reference electrode $(+230 \mathrm{mV})$. With an additional platinum wire in the central compartment, the potential of the growth medium and the electron flow between working and counter electrode could be recorded. To avoid development of high gas pressures in the culture vessel during fermentation. both compartments were connected with a $500 \mathrm{ml}$ bottle filled with $\mathrm{N}_{2} / \mathrm{CO}_{2}(90 \% / 10 \%)$ at a pressure of 1 bar. For experiments with lactate, glycerol, or propionate as substrates, $100 \mathrm{ml}$ cell suspension (grown in batch culture with $10 \mathrm{mM}$ lactate), substrate, and mediator were filled into the central compartment, and 5 inl medium was filled into the counter clectrode compartment.

Experiments in batch culture were carried out in $60 \mathrm{mil} \mathrm{serum}$ bottles. The bottles were fitled w1th $25 \mathrm{ml}$ medium, gassed with $\mathrm{N}_{2}$ $\mathrm{CO}_{2}(90 \% / 10 \%)$, and closed with butyl rubber stoppers. Substrates were added from freshly prepared sterile stock solutions. Experiments with lactate as substrate were performed exclusively with L-lactate. The growth temperature was $28^{\circ}-30^{\circ} \mathrm{C}$ in all cases.

\section{Analytical determinations}

Acetate and propionate were determined as described earlier (Dehning and Schink 1989) using a 6000 Vega Series gas chromatograph (Carlo Erba, Milano, Italy) equipped with flame ionization detector and a D-2000 1ntegrator (Merck-Litachi, Tokyo, Japan). $3 \mu \mathrm{l}$ samples were injected directly on a glass column ( $2 \mathrm{~m} \times 2 \mathrm{~mm}$ ) packed with 60/80 Carbopak $\mathrm{C} / 0.3 \%$ Carbowax $20 \mathrm{M} / 0.1 \% \mathrm{H}_{3} \mathrm{PO}_{4}$ (Supelco Inc., Bellefonte, Pa, USA) at a temperature of $120^{\circ} \mathrm{C}$. Hexacyanoferrate (III) was quantified in culture supernatants at $419 \mathrm{~nm}$ wavelength in an Uvikon 860 spectrophotometer (Kontron, Zürich, Switwerland). The system was calibrated with $\mathrm{K}_{3}\left[\mathrm{Fe}(\mathrm{CN}]_{6}\right]$ at various concentrations. Solutions of $\mathrm{K}_{4}\left[\mathrm{Fe}(\mathrm{CN})_{6}\right]$ did not absorb at this wavelength. For calculation of hexacyanoferrate (III) concentrations, the low background absorption of the respective cell suspension supernatants was taken into account. L-Lactate and glycerol were determined enzymatically by standard methods (Bergmeyer 1974).

\section{Growth yield determinations}

The cell densily of cultures was measured in $1 \mathrm{ml}$ cuvettes in a Zeiss PL 4 spectrophotometer at $578 \mathrm{~nm}$, and growth yields were calculated via optical densities which were calibrated by direct dry mass determinations in $500 \mathrm{ml}$ bottle cultures. An optical density of $\Delta \mathrm{E}_{578}=0.1$ corresponded to $35.4 \pm 3.0 \mathrm{mg}$ dry cell mass per liter. For growth yield determinations in the three-electrode poised-potential system, samples were taken with a sterile syringe directly from the culture vessel.

\section{Chemicals}

All chemicals were of reagent grade quality and abtained from Merck, Darmstadt, Fluka, Neu-Ulm. and Sigma, München, FRG. Cobalt (III)-sepulchrate-trichloride was obtained from $\Lambda$ ldrich, Steinhein, FRG. Enzymes were purchased from Boehringer, Mannheim, FRG.

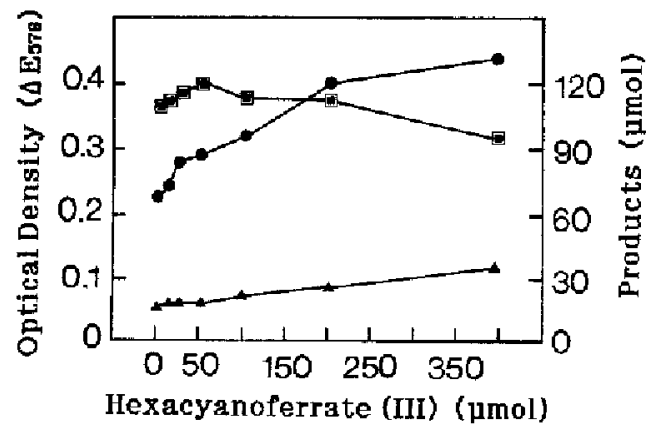

Fig. 1. Growth of Propionihucteriam freudenreichii with $5 \mathrm{mM}$ glyccrol $(125 \mu \mathrm{mol})$ and various amounts of hexacyanoferrate (III) in batch culture. Optical density: $\boldsymbol{\Lambda}$, acetate; $\square$, propionate

\section{Results \\ Reduction of hexacyanoferrate (III) in batch culture experinents}

Anaerobic growth of Propionibacterium freudenreichii was studied in batch culture experiments with glycerol as sole electron source and with hexacyanoferrate (III) at various concentrations (Fig. 1). Hexacyanoferrate (III) was reduced completely and the growth yields depended strictly on the amount of clectron acceplor provided. With higher amounts of hexacyanoferrate (III), propionate formation decreased and more acetate was formed. However, control experiments demonstrated that hexacyanoferrate (III) was reduced not only by glycerol oxidation but also by oxidation of yeast extract components and possibly of acetate. Without electron acceptor, propionate was formed as sole fermentation product, but glycerol was only incompletely degraded: of $125 \mu \mathrm{mol}$ glycerol provided, $19.5 \mu \mathrm{mol}$ remained in the growth medium in the experiment without electron acceptor, and $13.4 \mu \mathrm{mol}$ in the experiment with only $12.5 \mu \mathrm{mol}$ hexacyanoferrate (III) provided. This result was confirmed by batch culture experiments with $20 \mathrm{mM}$ glycerol as substrate (not shown). In these experiments, $15.4 \mathrm{mM}$ glycerol remained unused in the growth medium, even after an incubation time of $96 \mathrm{~h}$, whereas $20 \mathrm{mM}$ lactate was fermented completely within $48 \mathrm{~h}$. Also with lactate as electron source, added hexacyanoferrate (III) was completely reduced (not shown). As in experiments with glycerol as substrate, the growth yields increased with increasing electron acceptor concentrations, and the end product pattern was shifted towards higher acetate formation.

\section{Oxidation of glycerol, lactate, and propionate in the poised-potential anperometric system}

With hexacyanoferrate (III) as electron carrier (mediator), growth experiments with glycerol and lactate as substrates and $5 \%$ inoculum were carried out in the poised-polential culture system. In these experiments, growth stopped after $2-3$ doublings, and undegraded substrate remained in the growth medium. Similar negative results were obtained as well with various electron 


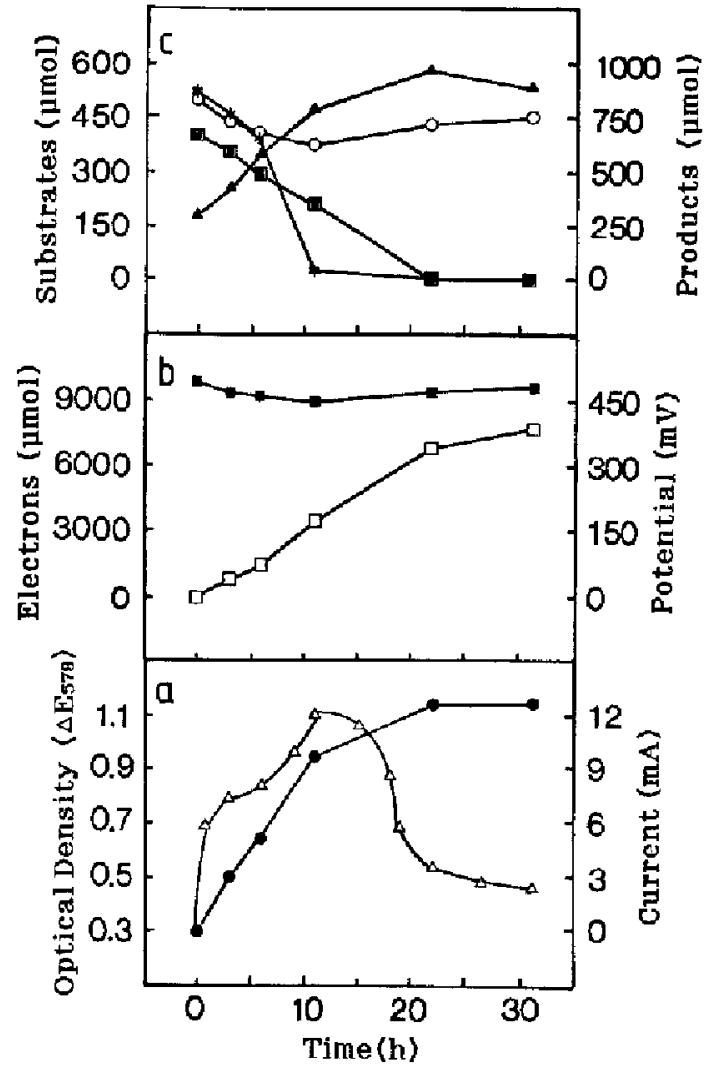

Fig. 2. Oxidation of $5 \mathrm{mM}$ glycerol with $5 \mathrm{mM}$ hexacyanoferrate (III) in the presence of regulated electrodes by a cell suspension of Propionibacterium frewdenreichii. a , Optical density; A, clcctrical current. $b \square$, Amount of electrons transferred to the working electrode; $\mathbf{\square}$, potential of the growth medium. $\mathbf{c} *$, Glycerol; $O$, hexacyanoferrate (IID); $\boldsymbol{\Lambda}$, acelale; $\square$, propionate

acceptor concentrations $(0.25-5.0 \mathrm{mM})$, variation of the poised electron potential, and addition of growth factors (vitamins and trace elements).

In cell suspension experiments starting with cell densities of $O D \geq 0.30$, hexacyanoferrate (III) was used as mediator at much higher efficiency. With $5 \mathrm{mM}$ glycerol as substrate $(500 \mu \mathrm{mol})$, coll growth was correlated with electron flow, and an electrical current up to $12 \mathrm{~mA}$ was recorded (Fig. 2a). Large amounts of electrons (calculated as the integrated current curve via the equation: $n_{e}=I \times t \times F^{-1}$ ) were transferred from the growing bacterial cells to the working electrode while the electron potential of the growth medium was kept nearly constant by continuous mediator reoxidation (Fig. 2 b). Thus, the concentration of oxidized mediator remained always high enough to allow glycerol degradation, which was finished after $11 \mathrm{~h}$ (Fig. $2 \mathrm{c}$ ). At this time, the maximum current was obtained. After complete glycerol degradation, growth continued at a lower rate for further $11 \mathrm{~h}$, and the current decreased only slowly. After $22 \mathrm{~h}$, acetate was found as sole fermentation product indicating that also all propionate in the cell suspension was degraded. At this time, $29.9 \mathrm{mg}$ cell material was formed, but a carbon recovery of only $89.1 \%$ could be calculated indicating that part of the substrate was oxidized completely to $\mathrm{CO}_{2}$. So, from the fermentation data given in Table 1 ,

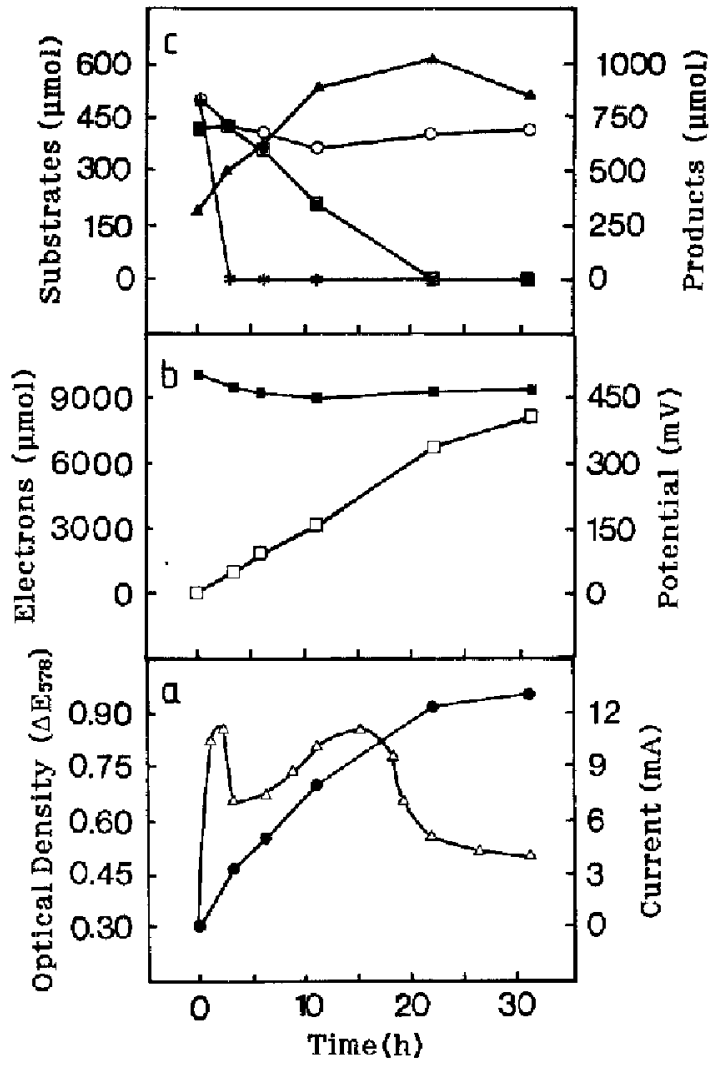

Fig. 3. Oxidation of $5 \mathrm{mM}$ lactate with $5 \mathrm{mM}$ hexacyanoferrate (III) in the prescnec of regulated clectrodes by a cell suspension of Propionibacterium freudenreichii. a $\bullet$, Optical density; $A$, curren $L$. b $\square$, Electrons; $\mathbf{Q}$, potential. c *, Laclate; $O$, bexacyanoferrate (III); $\wedge$, acetate; $\square$, propionate

the electron balance was calculated on the basis of the following reactions (values in $\mu \mathrm{mol}$ ): 387 propionate $\rightarrow 290$ cell material ( $484 \mathrm{e}^{-}$released); 127 propionate $\rightarrow$ $381 \mathrm{CO}_{2}\left(1778 \mathrm{c}^{-}\right) ; 152$ propionate $\rightarrow 152$ acctate $+\mathrm{CO}_{2}$ $(912$ e $) ; 500$ glycerol $\rightarrow 500$ acetate $+\mathrm{CO}_{2}\left(3000 \mathrm{e}^{-}\right)$. In summary, $6174 \mu \mathrm{mol}$ electrons were released by the cells during glycerol-propionate fermentation whereas $6760 \mu \mathrm{mol}$ electrons were transferred to the working electrode. Thus, $109 \%$ of the electrons released were recovered indicating that, in addition to glycerol and propionate, also yeast extraet components were oxidized either completely to $\mathrm{CO}_{2}$ or to traces of undetected products.

Similar results were obtained with $5 \mathrm{mM}$ lactate as substratc $(500 \mu \mathrm{mol})$ in lactate-grown cell suspensions (Fig. $3 \mathrm{a}-\mathrm{c}$ ). Lactate was degraded within $3 \mathrm{~h}$; acetate and few propionate were formed as fermentation products. After that, growth continued at a lower rate with propionate as electron source. After $22 \mathrm{~h}, 22.1 \mathrm{mg}$ cell material was formed and a carbon recovery of $83.9^{\circ} \%$ was calculated (Table 1). Assuming that $191 \mu$ mol propionate was completely oxidized to $\mathrm{CO}_{2}$, the electron recovery was $107 \%$.

Cell suspension experiments with glycerol or lactate as substrate in the presence of regulated electrodes were also performed with a hexacyanoferrate (III) concen- 

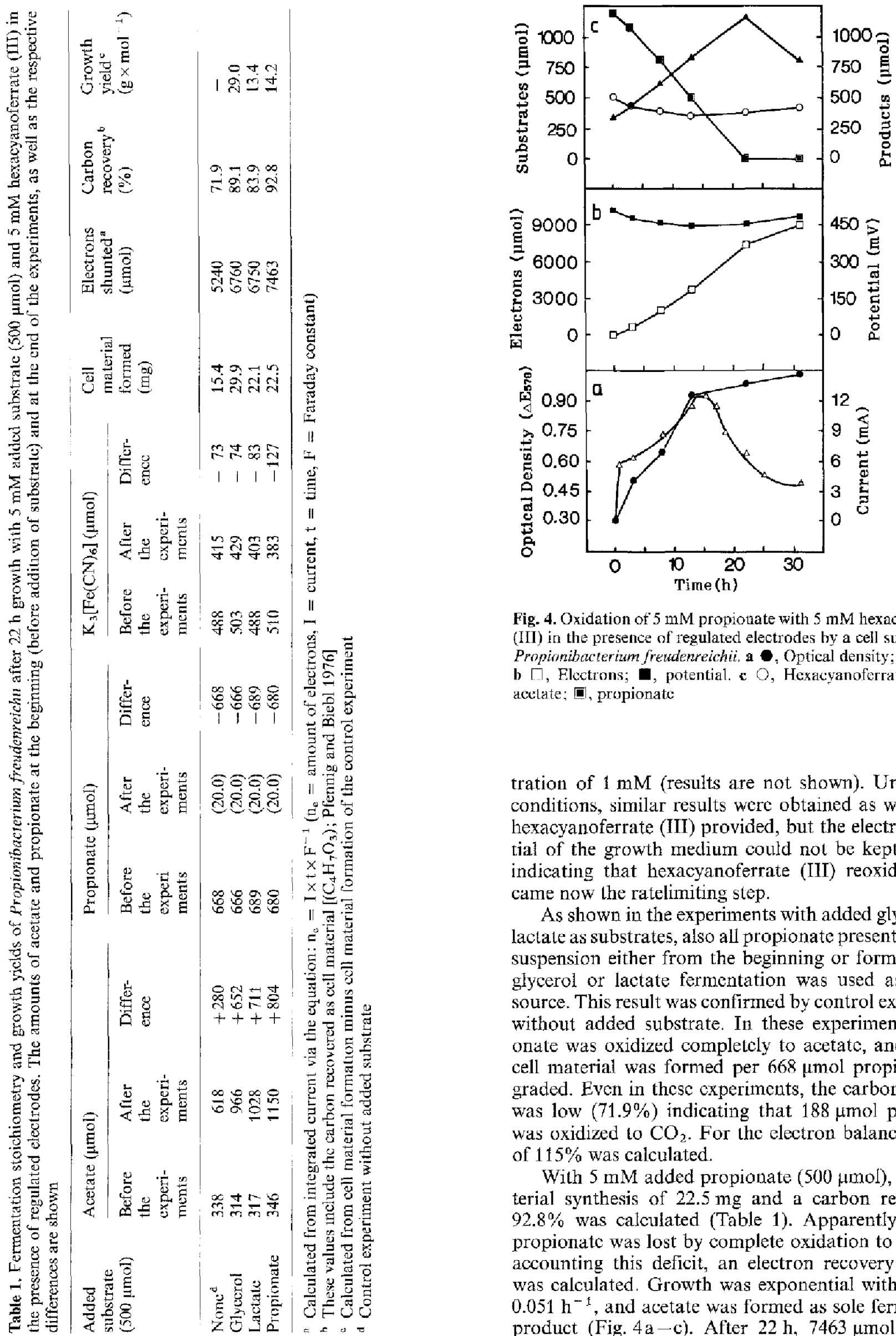

Fig. 4. Oxidation of $5 \mathrm{mM}$ propionate with $5 \mathrm{mM}$ hexacyanoferrate (III) in the presence of regulated electrodes by a cell suspension of Propionibacterium freudenreichii. a $\bullet$, Optical density; $\vec{A}$, current. b $\Pi$, Elcctrons; $\boldsymbol{\square}$, potential. $\mathbf{O}$, Hexacyanoferrate (III); $\boldsymbol{\Lambda}$, acelate; $\square$, propionato

tration of $1 \mathrm{mM}$ (results are not shown). Under these conditions, similar results were obtained as with $5 \mathrm{mM}$ hexacyanoferrate (III) provided, but the electron potential of the growth medium could not be kept constant indicating that hexacyanoferrate (III) reoxidation became now the ratelimiting step.

As shown in the experiments with added glycerol and lactate as substrates, also all propionate present in the cell suspension either from the beginning or formed during glycerol or lactate fermentation was used as electron source. This result was confirmed by control experiments without added substrate. In these experiments, propionate was oxidized completely to acetate, and $15.4 \mathrm{mg}$ cell material was formed per $668 \mu \mathrm{mol}$ propionate degraded. Even in these experiments, the carbon recovery was low $(71.9 \%)$ indicating that $188 \mu \mathrm{mol}$ propionate was oxidized to $\mathrm{CO}_{2}$. For the electron balance, a value of $115 \%$ was calculated.

With $5 \mathrm{mM}$ added propionate ( $500 \mu \mathrm{mol})$, a cell material synthesis of $22.5 \mathrm{mg}$ and a carbon recovery of $92.8 \%$ was calculated (Table 1). Apparently, $85 \mu \mathrm{mol}$ propionatc was lost by complete oxidation to $\mathrm{CO}_{2}$, and accounting this deficit, an electron recovery of $117 \%$ was calculated. Growth was exponential with a rate of $0.051 \mathrm{~h}^{-\mathrm{f}}$, and acetate was formed as sole fermentation product (Fig. $4 \mathrm{a}-\mathrm{c}$ ). After $22 \mathrm{~h}, 7463 \mu \mathrm{mol}$ electrons 


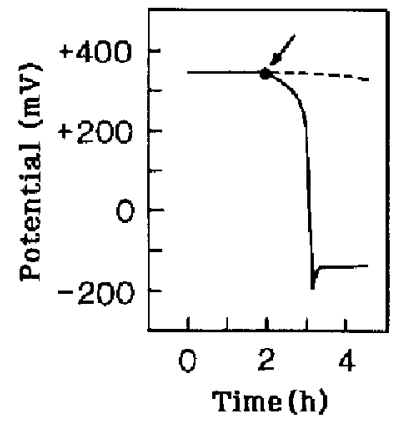

Fig. 5. Registration of the electron potential decrease of the growth medium with $20 \mathrm{mM}$ glycerol plus $25 \mathrm{mM}$ hexacyanoferrate (III) in the presence of regulated electrodes by a washed cell suspension of Propionihacterium freuderareichii. The arrow indica les the lime when hexacyanoferrate (III) roxidation was switched off. The broken line refcrs to the potential decrease of a control experiment without added substrate

were transferred to the working electrode $(6760$ with $5 \mathrm{mM}$ added glycerol, and 6750 with $5 \mathrm{mM}$ added lactate as substrates).

In cell suspension experiments with Propionibacterium shermanii, similar results as with $P$. freudenreichii were obtained (results are not shown). Glycerol, lactate, and propionate were degraded completely as well, and acetate was formed as sole fermentation product.

\section{Estimation of electron transfer potentials}

In cell suspension experiments with $P$. freudenreichi $i$ with $5 \mathrm{mM}$ propionate and $5 \mathrm{mM}$ hexacyanoferrate (III), propionate was degraded also at a poised potential of $+350 \mathrm{mV}$, but the maximum current was only about $3 \mathrm{~mA}$ and growth was linear with time. If hexacyanoferrate (III) was used at $25 \mathrm{mM}$ concentration, similar results were obtained as in experiments with $5 \mathrm{mM}$ hexacyanoferrate (III) at a poised potential of $+510 \mathrm{mV}$, indicating that propionate degradation at $+350 \mathrm{mV}$ was limited by the low concentration of oxidized hexacyanoferrate (III) at this potential rather than by the electron potential itsclf.

Electron potential decreases were measured with washed and in fresh medium resuspended cells. The washed cell suspension were grown with $20 \mathrm{mM}$ glycerol, lactate, or propionate plus $25 \mathrm{mM}$ hexacyanoferrate (III) at a poised potential of $+350 \mathrm{mV}$. After $2 \mathrm{~h}$, hexacyanoferrate (III) reoxidation was switched off and the electron potential of the growth medium was recorded. With glycerol as substrate, the potential reached a stable value at $-140 \mathrm{mV}$ after $1.5 \mathrm{~h}$ (Fig. 5). With lactate and propionate as electron sources, similar curves were recorded (not shown) and values of -105 , and $-100 \mathrm{mV}$ were determined. The linal potentials were subtrate-specific: in control experiments with washed cell suspensions in the absence of added substratc, the electron potential did not decrease significantly.

Experiments were carried out also with other mediators to estimate the electron transfer potentials. In cell suspensions with $0.5 \mathrm{mM}$ cobalt (III)-sepulchrate
$\left(\mathrm{E}_{0}{ }^{\prime}=-350 \mathrm{mV}\right)$ at a poised potential of $-310 \mathrm{mV}$, no growth occurred and no current was detected with $5 \mathrm{mM}$ added propionate or glycerol as substrates. With $5 \mathrm{mM}$ lactate, cells grew by fermentation, but no cloctron transfer to the working electrode could be recorded. In similar experiments with $0.5 \mathrm{mM}$ anthraquinone 2,6-disulfonic acid $\left(E_{0}{ }^{\prime}=-184 \mathrm{mV}\right)$ at a poised potential of $-144 \mathrm{mV}$, similar results were obtained with propionate and lactate as substrates, but few electrons were transferred while $5 \mathrm{mM}$ glycerol was degraded. In cell suspension experiments with $0.5 \mathrm{mM}$ indigodisulfonic acid $\left(\mathrm{E}_{\mathrm{a}}{ }^{\prime}=\right.$ $-125 \mathrm{mV}$ ) at a poised potential of $-85 \mathrm{mV}$, a current up to $0.8 \mathrm{~mA}$ could be recorded with all three substrates at the beginning of the experiments, but the current decreased rapidly after $2 \mathrm{~h}$.

\section{Discussion}

\section{Influence of hexacyanoferrate (III) reduction on the fermentation pattern}

In the present communicalion, incomplete oxidation of glycerol, lactate, or propionate to acetate by Propionihacterium freudenreichii with hexacyanoferrate (III) as clectron acceptor was demonstrated. In batch culture experiments as well as in experiments in the presence of regulated electrodes, hexacyanoferrate (III) proved as a well suited electron acceptor and mediator with Propionibacterium sp. Without hexacyanoferrate (III) provided, glycerol was only incompletely degraded, because cell material formation from glycerol releases excess electrons:

$4 \mathrm{C}_{3} \mathrm{H}_{8} \mathrm{O}_{3} \rightarrow 3<\mathrm{C}_{4} \mathrm{H}_{7} \mathrm{O}_{3}>+3 \mathrm{H}_{2} \mathrm{O}+5 \mathrm{H}+5 \mathrm{e}$

$\left.<\mathrm{C}_{4} \mathrm{H}_{7} \mathrm{O}_{3}\right\rangle$ stands for cell material (Plennig and Bicb) 1976). Some propionic acid bacteria, e.g., Anaerovibrio glycerini, release these excess electrons as molecular bydrogen (Schauder and Schink 1989). That about $4 \mathrm{mM}$ glycerol was degraded in our cultures without added hexacyanoferrate (III) was probably due to reduction of yeast extract components, e. g., reduction of aspartate to succinate (Crow 1987).

In batch culture, the extent of glycerol or lactate oxidation depended stoichiometrically on the amount of hexacyanoferrate (III) provided, and the fermentation pattern was shifted towards higher acetate formation. In the presence of regulated electrodes maintaining a constant concentration of oxidized hexacyanoferrate (III), propionate formation stopped completely and acetate was formed as sole fermentation product. So far, only oxygen and nitrate were known as external electron acceptors for propionic acid bacteria (Pritchard et al. 1977; Van Gent-Ruyters et al. 1975). Our results indicate that hexacyanoferrate (III) in combination with regulated electrodes is a third efficient way to shift the fermentation pattern of propionibacteria towards higher acetate formation.

The potential of electron transfer to hexacyanoferrate (III) cannot yet be defined exactly. Comparative studies 
Tahle 2. Amounts of ATP generated by Proptonibacterim fretdenreichii via substrate level phosphorylation (SLP) and electron transport phosphorylation (ETP) with hexacyanoferrate (III) in the presence of regulated electrodes

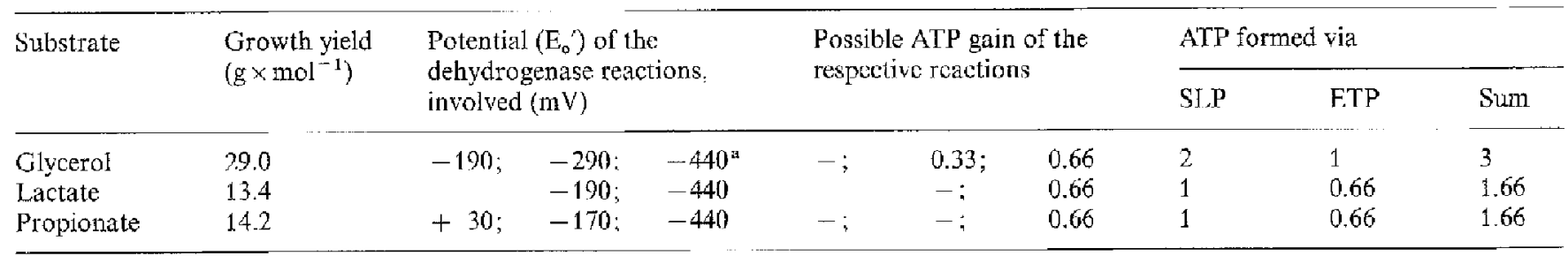

a. Calculated from $\mathrm{E}_{\mathrm{o}}$ ' for acetate $+\mathrm{CO}_{2} /$ pyruvate $(-700 \mathrm{mV}$; Zubay 1983 ) minus $260 \mathrm{mV}$ for reversible $\mathrm{ATP}$ synthesis under plyysiological conditions ( $50 \mathrm{~kJ} / \mathrm{mol}$; Thauer et al. 1977 )

with various electron carriers and glycerol, lactate, or propionate as substrates indicated that electron transfer was possible down to an electrode potential of -80 to $-140 \mathrm{mV}$. In propionibacteria electrons are transferred to fumarate, oxygen, and nitrate via cytochrome $b$ $\left(E_{\circ}^{\prime}=+30 \mathrm{mV}\right)$ (De Vries et al. 1973; Sone 1974; Van Gent-Ruyters et al. 1975), and/or menaquinone $\left(\mathrm{E}_{0}^{\prime} \approx\right.$ $-70 \mathrm{mV}$ ) (Schwartz 1972; Schwartz and Sporkenbach 1975). Our estimated electron transfer potentials indicate that reduction of hexacyanoferrate (III) $\left(\mathrm{E}_{\mathrm{o}}^{\prime}=\right.$ $+430 \mathrm{mV}$ ) occurs in the range of the potential of menaquinone.

Comparison of growth yields during growth with glycerol. lactate, and propionate

From growth yield determinations in batch culture with $P$. freudenreichii and glycerol concentrations of $1-$ $4 \mathrm{mM}$, a yield of $15.9 \mathrm{~g}$ cell material per mol glycerol degraded was calculated. Assuming a reaction stoichiometry of the membrane-bound proton ATPase of $3 \mathrm{H}^{+} /$ ATP (Maloney 1983), degradation of glycerol to propionate yields 1.66 ATP: 1 ATP is formed by substrate level phosphorylation (SLP), and 0.66 ATP by electron transport phosphorylation (ETP) via the fumarate reductase reaction (Schink 1988). Assuming that about $10.0 \mathrm{~g}$ cell material is formed per ATP generated (Stouthamer 1979), a theorctical growth yield of $16.6 \mathrm{~g}$ per mol can be calculated, confirming our experimental result.

In batch culture experiments with lactate as substrate, a growth yield of $8.9 \mathrm{~g}$ cell material per mol lactate degraded was reached. This value agrees well with the value determined by De Vries et al. (1973) $(8.1 \mathrm{~g} / \mathrm{mol})$. Degradation of 3 lactate to 2 propionate and 1 acetate yields $2 \times 0.66$ ATP via fumarate reductase and 1 ATP via acetate kinase reaction (Schink 1988). Thus, about 0.8 ATP per mol lactate degraded is formed and a theoretical growth yield of $8.0 \mathrm{~g} / \mathrm{mol} \mathrm{can}$ be calculated.

In the poised-potential amperometric culture system, glycerol, lactate and propionate were degraded to acetate, and growth yields of $29.0,13.4$, and $14.2 \mathrm{~g} / \mathrm{mol}$ with glycerol, lactate and propionate, respectively, were calculated. Electron transfer to hexacyanoferrate (III) appears to be linked to ETP under these conditions. The electron transfer potential to hexacyanoferrate (III) was estimated to be -80 to $-140 \mathrm{mV}$ (see above). Assuming that a minimum $A \mathrm{E}_{\circ}^{\prime}$-value of about $140 \mathrm{mV}$ is necessary to translocate 1 proton across the cytoplasmic membrane, 1 ATP, 0.66 ATP, and 0.66 ATP should be generated by ETP during oxidation of glycerol, lactate, and propionate, respectively to acetate (Table 2). Together with the amounts of ATP formed by SLP, total yields of 3.0 , 1.66, and 1.66 ATP can be calculated. The experimentally determined growth yields of $29.0 \mathrm{~g} / \mathrm{mol}$ glycerol and $13.4-14.2 \mathrm{~g}$ per mol lactate or propionate degraded agree well with those calculations.

Besides propionate, also acetate was partly degraded in our cell suspension experiments. Anaerobic acetate degradation with propionic acid bacteria was detected before only with $P$. pentosaceum in the presence of nitrate (Van Gent-Ruyters et al. 1975). Further investigations will clarify if under the conditions of the poised-potential amperometric system a complete citric acid cycle functions in P. freudenreichii.

\section{References}

Bergmeyer HU (1974) Methoden der enzymatischen Analyse, 3rd edn. Verlag Chemie. Weinheim

Chaix P, Fromageot C (1942) Les cytochromes de Propionibacterium pentosaceum. Trav Soc Chim Biol 24:1125-1127

Crow VL (1987) Properties of alanine dehydrogenase and aspartase from Propionibacteritum frewdenreichit subsp. shermanii. Appl Environ Microbiol 53:1885-1892

De Vries W, Van Wyck-Kapteyn WMC, Stouthamer $\Lambda H$ (1972) Influence of oxygen on growth, cytochrome synthesis and fermentation pattern in propionic acid bacteria J Gen Microbiol $71: 515-524$

De Vries W, Van Wyck-Kupleyn WMC, Stouthamer AH (1973) Generation of ATP during cytochrome-linked anaerobic electron transport in propionic acid bacteria. J Gen Microbiol $76: 31-41$

Dehning I, Schink B (1989) Malonomonas rubra gen. nov. sp. nov., a microaerotolerant anaerobic bacterinm growing by decarboxylation of malonate. Arch Microbiol (in press)

Emde R, Swain A, Schink B (1989) Anaerobic oxidation of glycerol by Escherichia coli in an amperometric poised-potential culture system. Appl Mictobiol Biotechnol 32:170-175

Fily A (1878) Über Spaltpilzgärung, IV. Ber Disch Chem Gcs $11: 1896-1899$

Kanck o M, Ishimoto M (1978) Efrect of nitrate reduction on metabolic products and growth of Propiombacterium acidi-propionici. Z Allg Mikrobiol 17:211 - 220

Maloney PC (1983) Relationship between phosphorylation potential and electrochemical $\mathrm{H}^{*}$ gradient during glycolysis in Streptocoecus lactis. J Bacteriol 153:1461-1470 
Pfennig N (1978) Rhodocycius purpureus gen. nov. and sp. nov., a ring shaped, vitamin $\mathrm{B}_{12}$-requiring member of the family Rhodospirillaceae. Int I Syst Bacteriol 28:283-288

Pfennig N, Biebl H (1976) Destuffuromonas acetaxidcus gen. nov. and sp. nov, a new anaerobic, sulfur-reducing, acetate-oxidizing bacterium. Arch Microbiol 110:3-12

Pritchard GG, Wimpenny JWT, Morris HA, Lewis MWA, Hughes DE (1977) Frcets of oxygen on Propionibacterium shermani grown in continuous culture. J Gen Microbiol 102:223-233

Schauder R, Schink B (1989) Anaerovibrio glycerini sp. nov, an anaerobic bacterium fermenting glycerol to propionate. cell matter, and hydrogen. Arch Microbiol 152:473-478

Schink B (1988) Konservierung kleiner Energiebeträge bei gärenden Bakterien. In: Präve P, Schlingmann M, Crueger W, Esscr K, Thauer R, Wagner F (eds) Jahrbuch Biotechnologie, vol 2 . Hanser, München Wien, pp 65-93

Schwarly AC (1972) A natural menaquinone participating in the electron transport system of the anaerobic Propionibacteritum shermanii. Abstr Commun Meet Fed Eur Biochem Soc 8 no 1089

Schwartz AC, Sporkenbach J (1975) The electron transport system of the anaerobic Propionibacterium shermanit. Cytochrome and inhibitor studies. Arch Microbiol 102:261 - 273

Sone N (1972) The redox reactions in propionic acid fermentation. I. Occurence and nature of an electron transfer system in Propionibacterium arabinosum. J Biochem $71: 931-940$

Sone N (1974) The redox reactions in propionic acid fermentation. IV. Participation of menaquinone in the electron transfer system in Propionibacterium pentosaceum. J Biochem 76:137-145
Stouthamer AH (1979) The search for correlation between theoretical and experimental growth yields. Int Rev Biochem Microbiol Biochem $21: 1-47$

Thauer RK. Jungermann K. Decker K (1977) Fnergy conservation in chemotrophic anaerobic bacteria. Racteriol Rev 41:100 180

Tschech A, Pfennig N (1984) Growth yield increase linked to caffeate reduction in Acetobacterium woodii. Arch Microbiol $137: 163-167$

Van Gent-Ruyters MLW, De Vries W, Stouthamer $\Lambda H$ (1975) Infiuence of ritrate on fermentation pattern, molar growth yields and synthesis of cytochrome $\mathbf{h}$ in Propionibacterizem pentosacetan. J Gen Microbiol 88:36-48

Van Gent-Ruyters MLW, De Meyere FA, De Vries W, Stouthamer AII (1976) Lactate metabolism in Propionibacteriam pentosaceum growing with nitrate or oxygen as hydrogen acceptor. Antonic van Leeuwenhoek J Microbiol Serol 42:217-228

Widdel F, Pfennig N (1981) Studies on dissimilatory sulfate-reducing bacteria that decompose fatty acids. I. Isolation of new sulfate-reducing bacteria enriched with acetate from saline environments. Description of Desulfobacter postgatei gen. now. sp. nov. Arch Microbiol 129:359-400

Widdel F, Kohring GW, Mayer F (1983) Studies on dissimilatory sulfate-reducing bacteria that decompose fatty acids. III. Characterization of the filamentous gliding Desulfonema limicola gen. nov. sp. nov, and Desulfonema magnum sp. nov. Arch Microbiol 134:286-294

Zubay G (1983) Biochemistry, 1st edn. Benjamin/Cummings, Menlo Park 